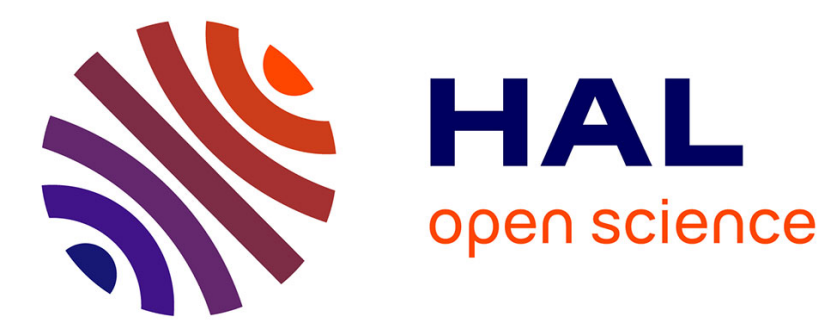

\title{
Revisiting the Importance of Detachment in the Dynamics of Competition
}

\author{
Ronan Le Velly, Frederic Goulet
}

\section{To cite this version:}

Ronan Le Velly, Frederic Goulet. Revisiting the Importance of Detachment in the Dynamics of Competition. Journal of Cultural Economy, 2015, 8 (6), pp.689-704. 10.1080/17530350.2015.1051489 . halshs-02081416

\author{
HAL Id: halshs-02081416 \\ https://shs.hal.science/halshs-02081416
}

Submitted on 27 Mar 2019

HAL is a multi-disciplinary open access archive for the deposit and dissemination of scientific research documents, whether they are published or not. The documents may come from teaching and research institutions in France or abroad, or from public or private research centers.
L'archive ouverte pluridisciplinaire HAL, est destinée au dépôt et à la diffusion de documents scientifiques de niveau recherche, publiés ou non, émanant des établissements d'enseignement et de recherche français ou étrangers, des laboratoires publics ou privés. 


\title{
Revisiting the importance of detachment in the dynamics of competition. Lessons from the marketing of an uncertain product.
}

\author{
Ronan Le Velly (corresponding author) \\ Montpellier SupAgro \\ UMR Innovation \\ 2, place Pierre Viala \\ F- 34060 Montpellier Cedex 2 \\ levelly@inra.supagro.fr \\ Frédéric Goulet \\ CIRAD \\ UMR Innovation \\ 73 avenue Jean-François Breton \\ F- 34398 Montpellier Cedex 5 \\ frederic.goulet@cirad.fr
}

\begin{abstract}
In this paper we adopt the framework of analysis of the economy of qualities (Callon et al., 2002) to describe the sales and marketing practices of a French farm supply company whose products have uncertain characteristics and disputed effects. We show that this uncertainty leads sales staff of the company to develop an argument designed to generate attachments but also, and even more importantly, detachments. We also show that these detachments and attachments do not just concern the farmer, the company and its products. To understand the competitive dynamics involved here, it is also necessary to focus on the associations that are broken and established with natural entities, actors in the supply chain, institutions of agricultural science and conceptions of the farming profession.
\end{abstract}




\section{Keywords}

Actor-Network Theory, Agriculture, Detachment, Qualities, Market, Uncertainty

\section{Introduction ${ }^{1}$}

In 'The economy of qualities', Michel Callon, Cécile Méadel and Vololona Rabeharisoa (2002) proposed a simple and intuitive definition of competition: it is a battle to attach consumers. As they put it, "[c]apturing, "attaching" consumers by "detaching" them from the networks built by rivals is the mainspring of competition' (Callon, Méadel, and Rabeharisoa 2002, 205). This project to study market dynamics through the prism of attachment, is part of the wider project of actor-network theory (Callon 1986; Latour 2005; see also McFall 2009b), and was shared with numerous other studies. By observing consumers during purchase or use (Cochoy 2004; Hennion 2004; Cochoy 2008) and 'market professionals' (Cochoy and Dubuisson-Quellier 2013) involved in design (McFall 2009a; Dubuisson-Quellier 2010; Aspers and Darr 2011; Reijonen and Tryggestad 2012; Buller and Roe 2013), marketing (Azimont and Araujo 2007; Barrey 2007; Kjellberg 2007; Bird-David and Darr 2009; Deville 2012; Mallard 2012), or prescription (Karpik 2010; Dubuisson-Quellier 2013), research has revealed the nature of the socio-technical arrangements which make up the relationships between companies and their customers, consumers and their products. At the heart of these relationships are of course commercial spaces and sellers, but also the products and packaging, brands and advertising, shopping lists and loyalty cards, taste tests and focus groups, economic theories and marketing tools, etc. In this context, it is also the importance of the activities of qualification, judgment, calculation and valuation, carried out by all market actors, which have been the subject of theoretical clarification (Callon and Muniesa 2005;

\footnotetext{
${ }^{1}$ This is a revised version of an article initially published in French (Goulet F., Le Velly R., 2013, "Comment vendre un produit incertain? Activités de détachement et d'attachement d'une firme d'agrofourniture", Sociologie du travail, 55 (3), 369-386). This work was supported by the CARPE inter-unit network, SAD Department of INRA. The authors thank Camille Amet for her support in data collection, Antoine Bernard de Raymond, Alexandre Mallard, Antoine Roger and the Journal of Cultural Economy reviewers for their comments and advice, and Peter Hamilton for its translation.
} 
Çalışkan and Callon 2010; Vatin 2013) and of extensive empirical surveys (MacKenzie and Millo 2003; Doganova and Eyquem-Renault 2009; Poon 2009; Van Hoyweghen 2013).

The results of this work are considerable, but they do not seem to respond fully to the proposals set out in 'The economy of qualities'. Thus, by comparison with the attachment process, the process of detachment has been rarely described (for a similar finding in the sociology of innovation and more broadly as a contribution to the sociology of detachment, see: Goulet and Vinck 2012). Even the work on the 'captation' and 'channelling' of customers (Cochoy 2007; Trompette 2007; Deville 2012), two terms that suggest as much detachment as attachment, have not followed these two paths in a balanced way. However, we can hypothesize that accounting for the processes of attachment is not enough to fully understand competitive dynamics.

This article aims to give equal attention to the operations of detachment and attachment. It relies for this on a field survey (see box) conducted with a farm supply business - which we call NutriAgri - and its farmer customers. The advantages of using this case are understood in terms of the project discussed above: in France, the sale of agricultural inputs and the advisory services that usually accompanies them are under intense competition today, replacing the quasi-monopolies of the co-operative and the Chamber of Agriculture that have existed in the past. NutriAgri must thus act to retain its existing customers and attract new ones. However, the choice of this case has also been guided by a second characteristic.

The products marketed by NutriAgri can be considered as particularly uncertain products: their chemical composition is kept secret, their effectiveness is controversial, and they are often lampooned in the agricultural world as 'snake oil'. Even the most active promoters of these products, the technical sales staff who go from farm to farm to sell them, make no attempt to reduce uncertainty about their composition. However, over the past ten years, NutriAgri has managed to conquer a growing market among the ranks of French farmers. We are then faced with an existing situation that does not conform to the teachings of either economics or economic sociology (Akerlof 1970; Beckert 1996), a mixture of increased commercial exchange and uncertainty about product properties. How is this possible? How does a company manage to sell products for which there is only tenuous evidence of their efficacy?

Our study combines an interest in the theoretical framework of attachment-detachment with another concerned with uncertainty about products. In a symposium on quality (Musselin and Paradeise 2005), Callon proposed to dispense with the notion of uncertainty, especially where 
this notion suggests a simplistic distinction between two market configurations, firstly where the quality of products is uncertain and the coordination requires some processes of qualification and judgement, and secondly where this uncertainty is resolved and the market is regulated by price. According to Callon, an approach through attachment makes one through uncertainty unnecessary, if not obsolete: research studies of markets should focus on the devices and processes that weave these links, rather than on those that establish confidence in a context of uncertainty. In this article, we adopt a less trenchant view. We do not think that the most important point in Callon's reasoning is banning the notion of uncertainty but is instead the idea that uncertainty is not an intrinsic property of some products. With the NutriAgri case, we will show that the uncertain properties of some products can be the subject and the result of ongoing debates. From this point of view, our analysis will indeed be faithful to the programme proposed by Callon for the study of technological controversies (Callon 1981). ${ }^{2}$ These controversies about quality are at the very heart of attachment and detachment processes. In the second part of the article, we will explain that the detachment activities performed by NutriAgri agents are even more important because the properties of their products are the subject of intense criticism. Before customers can be attached to NutriAgri's products, we will establish that they have to be detached from the competitors' products, but also from other entities such as the phosphorus present in these latter products and the scientific and agricultural institutions that recommend the use of phosphorus fertilization. In the third part of the article we will similarly establish that attachment is not something which concerns just the customer and the product. Attachment to NutriAgri products presupposes instead a form of 'dissolution' of the product in a comprehensive solution, including advice and support, new natural and material entities, renovated cultural practices and 'another vision of agriculture', as the NutriAgri company slogan would claim. These activities of detachment and attachment will be presented in two successive stages. But it is important to state that they are nevertheless not sequential: NutriAgri's technical sales representatives aim to perform

\footnotetext{
${ }^{2}$ We have considered using the terms "controversial products" to avoid the pitfalls of the "uncertain products" concept that Callon has clearly stated. We have decided to use these latter terms because we wanted to address directly the question of the uncertainty of the quality of the products. Referring to "controversial products" could also have been misleading as this expression has been mainly used in market research to refer to socially sensitive products such as alcohol, cigarettes or contraceptives (Waller, Fam and Erdogan 2005).
} 
these two indivisible activities simultaneously. Before developing these points, we will devote the first part of the article to presenting the NutriAgri case.

\section{Box. Fieldwork and Methods}

This research is mainly based on fieldwork conducted in 2011. Initially, we conducted semistructured interviews with three executives of the company. Then we conducted participant observations with eight technical sales representatives in France and Belgium, spending one to three days with them during their visits to their customers. Semi-structured interviews were conducted with each of the technical sales representatives, dealing in particular with their personal career paths, their relationships with their customers and colleagues, their sales practices and advice to farmers. We also took part in five days of meetings organized by the company in Brittany and Picardy, during which customers were invited to discuss technical issues and take part in convivial activities. This was an opportunity to talk with other technical sales representatives of NutriAgri and a large number of farmers. Similarly, we followed the firm on its stand during an agricultural fair of national importance. Semistructured interviews were also conducted with six farmers who were customers of the company, to discuss their attraction to the brand and its products. Finally, we also met NutriAgri's competitors in the field of advice and/or sale of inputs, in order to gather their views on the company.

We carried out some 26 semi-structured interviews in total, and in addition spent twenty days conducting participant observation in the field. We then transcribed the interviews and observation notes, and coded this data inductively in order to elicit recurring themes within the discourse of our subjects (differentiation from competitors, challenges to agricultural science, etc.). This thematic analysis thus became the methodological framework on which this article was constructed.

\section{The contentious and uncertain nature of NutriAgri's products}

To better understand the conditions and the drivers of marketing work conducted by the NutriAgri company, we need to look at the main characteristics of the firm, especially the contentious and uncertain nature of its products. 
NutriAgri is an SME, created in the early 1990s, which manufactures and sells mineral products for soils, crops and livestock (feed, fertilizer, etc.). Its economic scale is low. The French Union of Industries of Fertilisation, of which NutriAgri is not a member, but represents $91 \%$ of French production, estimated that sales of fertilizer and supplements by its members in France were 2.3 billion euros in 2010. By comparison, the turnover of NutriAgri was only $20 \mathrm{~m}$ Euros in 2011. However, over the past ten years, the company has experienced strong growth: an 80\% increase in turnover between 2004 and 2011, and expansion from 40 employees in 1993, to 106 in 2004 and 130 in 2011. Its customers are found in both crop production and livestock farming, in farms of various sizes, using modes of production that range from the most conventional to organic farming. The only characteristic that particularly defines NutriAgri customers is their unsystematic but especially widespread use of simplified soil cultivation techniques (i.e. direct seeding, no-tillage ${ }^{3}$ ). The management of the company explains this success by the particular nature of its technologies and services. According to them this is to offer a 'comprehensive approach', the 'NutriAgri concept', including product support and field sales technicians in the company. They represent more than $70 \%$ of the workforce of the company, crisscrossing the countryside in their vans decked out with the company logo, and especially its slogan: 'Another vision of agriculture.' The company chose in fact to market its products directly, and not through intermediaries such as wholesalers or co-operatives. The business of agricultural and technical advice is central to the mission of the technical sales force, providing advice concerning not only the products themselves and fertilization, but the farm as a whole (management of cultivated areas, of livestock, and crop protection treatment). This is why NutriAgri claims a 'comprehensive approach', far exceeding the solely agronomic properties of its products. Nevertheless, these products remain at the heart of customer interaction: the advisory service is not invoiced as such, just the products. It is therefore these inputs, sold in plastic containers delivered on pallets or in bags of several tens or hundreds of kilos, that provide the market transactions between the company and its customers.

The technology marketed by NutriAgri is partly secret and partly contentious. The 'core' is the term used by company directors to identify the active ingredient in products developed

3 These techniques, based on the abandonment of tillage and deep ploughing, have the particular function of reducing soil degradation and stimulating biological activity. A major difficulty limiting their wider use by farmers is the lack of knowledge available to implement them (Goulet, 2013). 
forty years earlier, and whose formula is kept secret. According to the directors, the 'core' makes it possible to optimize the biological functions of soil, plants and animals through electrolytic and catalytic effects. The rest of the product's composition is well known chemicals: its base is lithotame (seaweed rich in limestone minerals and trace elements), to which is added preparations of magnesium, potassium and other minerals. The controversy concerns - or rather follows from - what the products do not contain: phosphorus. The mineral phosphorus is one of three basic elements (with nitrogen and potassium) used in the fertilization of agricultural land. It is one of the main constituents of 'basic' manure whose annual benefits are recommended to farmers by technical extension organizations, on the basis of a strong consensus within the agricultural sciences. Yet NutriAgri does not incorporate phosphorus in its products and goes so far as to strongly recommend to farmers that they should not use this element. According to the management and technical sales staff of the company, phosphorus is responsible for uncontrolled proliferation of bacteria in the soil, which leads to soil acidification, poor degradation of organic matter, and an increase in crop disease. Such arguments are very far from attracting support from the majority of research and agricultural development institutes. Many farmers also see them as an aberration, a view supported by the discourse of NutriAgri's competitors. The products sold by NutriAgri might thus be not merely ineffective ('snake oil') but also dangerous.

\section{Detaching farmers from phosphorus and detaching oneself from competing products}

In the construction of market relationships, generating attachment is an important task, but it is nothing without a symmetrical process of detachment. From this point of view, observation of the tours made by NutriAgri's technical sales staff is highly instructive. It tends to show that the work of detachment is an essential if not primordial aspect when the characteristics of the product are challenged a priori. This is particularly true during visits to prospects who have never ordered or customers who only partially use the company's product. The aim of technical sales staff is thus to respond to the doubts expressed about NutriAgri's supplies. This involves questioning the benefits of phosphorus as an input and the scientific and agricultural institutions that recommend it (section 2.1). Then in addition NutriAgri must differentiate itself from other input suppliers, some selling very different products, some offering very similar products (section 2.2). 


\subsection{Detaching farmers from phosphorus, science and its institutions}

Uncertainty about the composition of the products is a characteristic which NutriAgri staff encounter on a daily basis. The uncertainty related to the removal of phosphorus in fertilization requires the technical sales staff to explain the reasons for its absence. For this, and alongside the technical arguments advanced to support their products, they develop a mass of arguments and supporting evidence aimed at discrediting their competitors' products containing phosphorus, and challenge the beliefs of farmers about this element. Their discourses thus put emphasis on the as yet unrecognized environmental harm caused by the use of phosphorus fertilizers. The spectre of future regulatory constraints related to excess intake of phosphorus is advanced to strengthen this strategy of detachment. Hence the comment of a technical sales representative from the Ardennes that 'phosphorus will soon be banned. Nitrates are not a pollution problem, but phosphates are, and nitrogen is required, not phosphorus.' It is thus the harmful effects of agricultural phosphorus that are being advanced. 'Phosphorus is an activator, it boosts the plant, but also diseases and the degradation of organic matter. That's the short term, we are offering you the long term', as the same technical sales representative explained for example during a visit. To support this argument, the technical sales representatives solicit material evidence drawn from the immediate environment of the farmer. For example, it is commonplace for them to cross the road with a customer and take a discreet look at the plot of a neighbour who continues to use phosphorus, and which to some degree is thus a kind of control plot. The NutriAgri representative points out signs of poor plant health or soil condition to his customer - such as short roots, yellowing leaves, degraded soil structure, lack of biological activity, etc. Proof of the dangers of phosphorous is thus provided, as well as an incentive to no longer use it. An indepth observation made by digging a hole in the ground is then carried out on the client's land, giving the opportunity to the technical sales representative to highlight the presence of earthworms, abundant foliage and moss on the ground, the signs of "good health".

If one follows the argument of the company's representatives, mineral phosphorus is thus a superfluous input, at the heart of a short-term logic of action, and one that is harmful even for the proper functioning of crops and soils, as an ally of parasites and an enemy of the fertilization of crops. Through the problematization of the use of this element, it is being made into a 'passage point to avoid' (Goulet and Vinck 2012).

The detachment process continues with a challenge to agricultural research institutions that encourage farmers to use phosphorus and fail to objectify the qualities of NutriAgri products. 
Many farmers share the feeling that this research has for the last half a century undervalued their own ability to think and act autonomously, and this is a useful tool for NutriAgri's representatives. It is above all the method of evaluation of agricultural innovations and practices in terms of the criteria of experimental science that is questioned. More precisely, it is the cutting off of experimental objects and factors practiced by science which becomes irrelevant when one is interested, as NutriAgri claims, in biological processes and complex interactions within ecosystems. As a technical sales representative in the Eure-et-Loir explains to us before he begins his tour: 'The agronomic reality is that soil is a living environment. (...) And a living environment is not governed by the laws of arithmetic, but by the laws of life.' Science and its tools, which can seem to be cut off from the 'real' world by taking refuge in its laboratories, are singled out, in favour of a pragmatic and specific approach: 'They want to model agriculture, to record plot yields, but it is a bit stupid to record yields this year, because it is an unusual one. So we will not follow what this model tells us, we'll do what we can do, using our experience,' says a technical sales representative in the Oise. The technological tools developed by scientists or engineers from agricultural research institutions to monitor crop plots, and to support farmers in their decision-making are then questioned. As a technical sales representative in northern France says to one of his customers about the importance of going into the field to assess the need to apply a fungicide to a crop: 'If you don't go to the field, you won't know. If you just use the "satellite" [the GPSbased device] it tells you to do nothing.'

This science, which is both unable to account for complex natural phenomena and is removed from actual reality, cannot be a substitute for field experience. A technical sales representative in Moselle summarises this: 'It is better to have experience that illuminates than science that dazzles. (...) It is not about micro-plot tests but whole field trials, done by the farmer. He is on-site.' The advisory activities of chambers of agriculture and co-operatives are also called into question. Their agents are now considered no more than 'office advisors' or 'computer technicians'. In the end criticism is focused on agricultural training, equated with this agricultural technoscience that is remote from the real concerns of farmers. One technical sales representative, to describe his 25 years of professional experience and satirise the educational system, recalls: 'I am bac+25!'4 Another, working in the Oise, said: 'It's not where life is learned. (...) School provides your framework, when you leave you're thinking in a straight line. The strength of people is that they can adapt to every situation and it is not

\footnotetext{
${ }^{4}$ This is a sarcastic allusion to the commonplace use of years of higher education following the baccalauréat diploma in French job advertising: for instance, $\mathrm{Bac}+5$ is the equivalent of a master's degree.
} 
school that teaches you that. School teaches you that it does not matter if there is a problem: there will always be a chemical solution.'

Again, competitors' products and their associated modes of thought are accused of acting locally and in the short term without consideration of the broader agronomic effects. In contrast, it is the 'BSP' (bon sens paysan), an acronym sometimes heard during our survey to denote the 'peasant common sense' that is valued through the dissociation of experimental science and the institutions that relay it. This dissociation is expressed at a rhetorical level but is also given real material form in the slogans prominently displayed on the company's vehicles. Thus the technical sales representatives insist - usually by alluding to this brand visibility - on the fact that their slogan is not just fine words spoken during a private meeting with a farmer. Indeed it is a real commitment by anyone's standards: 'NutriAgri is (...) another philosophy, another idea of agriculture. And that's been written on the trucks for 17 years' (technical sales representative in the Oise).

\subsection{Detachment from other input suppliers}

The second aspect of the process of detachment, conducted in conjunction with the first, relates directly to competitor input suppliers. These consist of crop protection firms and wholesalers, as well as agricultural co-operatives who buy wholesale and sell to their members. These providers can supply very different products from NutriAgri but also very similar ones. NutriAgri is indeed not the only firm to offer a range of mineral nutrient inputs for soil, plants and animals. The first of these competitors, which we call MinéPlus, even sells products that contain the same 'core' as those of NutriAgri. In fact NutriAgri was created in the wake of dissension among the directors and shareholders of MinéPlus, which led to the coexistence of these two companies. Other fertilizer manufacturers have also developed ranges of relatively similar products. This development is a favourable argument for NutriAgri's representatives. They rely on this fact to say that they were right from the beginning. 'Before we were bandits, now we are being copied', quips the technical sales representative from the Oise. But this also implies being able to distinguish themselves specifically from these new entrants to the market.

Against MinéPlus, NutriAgri's representatives cannot simply repeat the arguments outlined in the previous section. They put the emphasis on having a distribution system based on a direct relationship and support for customers, on a physical "on-farm" presence. Unlike MinéPlus, NutriAgri does not delegate its distribution to wholesalers or co-operatives. This enduring 
attachment of NutriAgri to its products enables its representatives to present themselves as competent technicians that perfectly know the right use of the products, and to denounce the behaviour of MinéPlus' sales representatives.NutriAgri staff, although salespeople themselves, notably emphasise the 'commercial' behaviour of their competitors. These are presented as people animated solely by the pursuit of gain who would do anything to increase their sales. Two technical sales representatives of NutriAgri, in the Ardennes and the Oise, emphasized that: 'Whenever somebody from the co-ops makes a visit, it's to book an order.'; 'I don't call the co-ops' staff technicians, no I don't call them technicians but sellers, they put pressure on in relation to sales.' Then the direct-sales strategy of NutriAgri is recalled, this time to affirm the need to detach from intermediaries, who are accused of enriching themselves at the expense of farmers. To emphasise their distance from these "conventional" suppliers, some customers therefore have no qualms in showing the material signs of the successful detachment which they have made. This is the case for instance when they hang a NutriAgri sticker above their barn to signify to the traditional advice or input suppliers that they will have no business with them. It is also the case when, in a subtle game played between technicians and customers to confirm the reality of detachment, the former begin, when they arrive on a farm, by checking in the fertilizer store that the farmer did not buy any phosphorus fertilizer. The customers respond to that by proudly pointing to the empty area previously occupied by fertilizer or plough.

In sum, we see how the attempt at detachment made by NutriAgri staff, even if it mainly concerns competing products and actors, increases in generality and includes larger entities. By relying on discursive, cognitive and material resources, actors promote and construct detachment not only vis-à-vis phosphorus, but also consultancies, co-operatives, wholesalers, multinational agricultural suppliers, agricultural research institutes and schools. These actors, their products and services, their knowledge and practices, and finally their vision of the farming world, are assembled into a sociotechnical network embodying an agriculture which ought to be discredited, and symmetrically opposed to the sociotechnical world organized around NutriAgri and its products. This strategy is not without flaws and ambiguities. For example, the remuneration of technical sales representatives is based on the number of tons of product they have sold, plus the value of their sales; and their criticism of the behaviour of the other salespersons cannot lead to the conclusion that they are selfless. In any case, analysis of the work of technical sales representatives for NutriAgri shows the importance of the activity of detachment. It is a way of challenging the assessment frameworks that are unfavourable to 
it, which lead to their products being thought of as ineffective and dangerous, and to open up the possibility of other ways of seeing. It is difficult if not impossible to objectify the qualities of their products, and this makes detachment essential, and makes it appear - initially at least — as primordial compared to the techniques of attachment themselves.

\section{Attaching customers to the company, its products and services}

For Callon and his co-authors, attachment works through a singularization of the product: a close link must be established between the company and its customer, the product and its user (Callon, Méadel, and Rabeharisoa 2002; Callon and Muniesa 2005). In the case of NutriAgri this singularization is intimately linked to the individualized support provided by technical sales representatives (section 3.1). The fieldwork also shows that attachment additionally requires association with new entities: the detachment from the routines and socio-technical networks that support them is coupled with the establishment of new ways to see and produce (section 3.2). Successful attachment is then characterized by the formation of relationships between the staff of NutriAgri and their customers that extend far beyond the exchange of products and are marked by a community of values and beliefs (section 3.3). Attachment to this uncertain product is not in the end directly about the product itself: it is driven through associations between the product and other factors of technical, cognitive, or emotional orders, or in other words a form of dissolution of this product in a comprehensive solution.

\subsection{Singularization of the relationship with the product through advice}

We have seen that the issue of support to customers through advice constitutes a backbone in the differentiation of the company compared to its competitors. Monitoring of technical sales representatives during their rounds shows that it is also a key element of the attachment between customers and NutriAgri as a company. It is always the same representative that visits a given farm. Thus the relationship between farmers and their technical sales representative clearly goes beyond the purchase and sale of related products. It involves an advisory and extension aspect, which makes it a long-term relationship, and erases the boundary between product and service market (Musselin and Paradeise 2005). Thus, even when the sale has been concluded during a previous visit, the technical sales representatives themselves ensure the delivery of products. According to the technical and sales director of the company, this aspect is crucial: it allows better contact with farmers, the opportunity to visit the places of production and observe animals and crops. During their visits, the technical 
sales representatives offer to perform a 'farm tour', an observation of the different plots that make up its operations with the farmer. A discussion is held on each one to determine the condition of the plants, soil and animals, and consider what action needs to be taken.

A farmer told us: 'I call [the technical sales representative] as soon as I ask myself a question on anything related to crops, rarely on NutriAgri. It is part of the product.' In their discussions with farmers, technical sales representatives also validate the idea of dissolving the product in the general organization of the farm. Sometimes at the risk of devaluing the product, they hold it back a little in order to say that it is no good without being used properly in the singular context of the farm and the farmer's plans. Ultimately, vendors and customers share agreement on the fact that what makes the difference, the quality of NutriAgri's offer, is not the product as such, but the technical solution found on the farm. Interviews held with farmers show that this effort of attachment of the product to the farm situation, through advice and support, is also what allows users to accept doubts over the composition and effects of the product. One of them, a customer in the Aisne for six years, recalls: 'On the results I'd say it's one-third the product, two thirds the support. I'm not sure that the products work, but this is not the problem.' The local technical sales representative also confirms: 'The product without the discussion is nothing. And vice-versa.' The boundary between what are intrinsic properties of the product and its uncertain cognitive and relational environment is tenuous: what counts, what attaches the customer, is the technical organization as a whole, such as it is applied on the farm, and not just the product, which is moreover too uncertain or challenged.

The success of each customer, of each farm with its own constraints, also became a slogan for the company, such as for example at a regional meeting where the theme and the slogan were: 'Everyone performs with NutriAgri'. The discourse of the firm and its staff thus resonate with the powerful trends within the agricultural world mentioned above, namely the quest for autonomy, either in inputs or in the production of knowledge. One customer, a producer of grain and beets in the Somme, says in an interview: 'I saw the soil degradation, the rise of mechanization, the rise of the technician technology that took away observation and common sense from the peasant farmers, they were reduced to being manufacturers under the technology. Farmers became recipe appliers. They were made to feel guilty for actions that are common sense to them. NutriAgri is the freedom to decide on the basis of observation.' 


\subsection{Attachment to new crop practices and new natural entities}

In the approach to technical advice that the company representatives develop with their customers, adoption of branded products is almost always accompanied by other and very important changes in practices that alter the state of the cultivated environment. This is particularly the case for the abandonment of ploughing and simplification of tillage, that the company strongly encourages, and which induces profound changes in farmers' routines (planting dates, weed management, use of new equipment) and in the behaviour of plants and soil. Similarly the technical sales representatives often involve their customers in thinking about the reduction of pesticide applications. No longer use phosphorus, no longer plough, less treatment: the recommendations turn around what not to do rather than what to do. Talking about this subject one farmer, referring to his first contact with his technical sales representative, confirms that: 'He began by saying what should not be done.' Attachment to the 'NutriAgri concept' thus reinforces a series of detachments operating to divert farmers from their original routines. There are actually a multitude of factors that change at the same time in the plots and farms, and it becomes very difficult to isolate and measure the effect of the products among the other changes being implemented.

During the visits, the representatives only deal with very few effects of the product as such: they treat a variety of technical topics, such as those just described, paying particular attention to biological dynamics at work in the soil, and the interaction between soil and plants. The company has played a founding role, since its inception in the early 1990s, in teaching and dissemination of a discourse on the effects of no-till on populations of earthworms and other organisms living in the soil. In a way comparable to that shown by Latour on the subject of microbes (Latour 1988), the association of these new natural entities with social practices involves making entities visible which were previously invisible because they were buried deep in the ground or of microscopic size. The visits made by technical sales representatives include trips to observe the farmer's plots, and use of a spade to dig a hole and inspect the condition of the population of earthworms and other galleries, waste or traces of life in the soil. It is thus a question of taking the pulse of the plots, of having a material contact with soils, plants and animals, of practicing and staging the local field agronomy around which the firm seeks to differentiate itself from its competitors. The spade, and to a lesser extent the $\mathrm{pH}$ meter and thermometer also used to monitor the soil, thus embody the specificity of the advice provided by NutriAgri. During one visit, a customer said: 
'All the technicians who visit, who give us a list of crop protection products... They never have a spade in the truck, they never talk to us about earthworms! (...) NutriAgri means the observation and return to the land, and to the observation of the soil.'

This conversion in ways of seeing is part of a long term process. The technical sales representatives always explain to their prospects and new customers that it is useless to try to assess the product over a single year, so they must commit for several years at the outset. The argument is based on the fact that the turnaround from declining activity in microfauna and microflora in the soil does not happen instantly. However, to make it possible for farmers to see the benefits that they can expect after their adoption of the 'NutriAgri concept' technical sales representatives also depend on examples from farms that have been working in this framework for several years. These model farms are then chosen as much for their agronomic and economic performance as for the image they convey: farmers must demonstrate practical intelligence and innovative curiosity, farms must be clean, etc.

In the same way that detachment targets a network of entities larger than just the competitors' products, what NutriAgri ultimately provides to those who become customers is in the end more than just a product. It is a product included in a comprehensive technical solution, and personalised advice, but also another way to understand biological realities, agronomic processes, agriculture and farmers. The framework of evaluation has been re-opened and is then closed to accommodate new features and extend the time horizon.

\subsection{A community of values between sellers and customers}

Actors who are critical of the 'NutriAgri concept' often describe the members of its group as a 'sect'. This is aimed in part at challenging the practical and epistemic changes associated with it, but it is also due to the characteristics of the relationship between the farmers who are most involved in the process and the staff of NutriAgri. When the work of attachment has been fully achieved, as is the case with the oldest and most loyal customers, this relationship is marked by shared convictions, which actually give the observer the feeling of being in the presence of a form of epistemic and moral community.

This feeling is firstly manifested in terms of the modes of discourse used by the more confident farmers, who often recount their decision to adopt the NutriAgri concept as a moment of true conversion. This conversion is described as a revelation, a bifurcation, which makes them realize they will never be the same, and that their job and their soils are no longer 
what they were. The Somme cereals and beet producer mentioned earlier, who has been a NutriAgri customer for 10 years, recounts this turning-point:

'In the first year of no-till, I went on holiday in late January, and when I returned oats had disappeared on some plots. [The NutriAgri technical sales representative] came to visit, we went into the fields with a spade and we looked at the earthworms and their working of the land: lots of small mounds, they'd taken the straw to the bottom. And I thought the oats were gone with the wind... Then we went to another parcel where the oats were still there: and we saw only one turricule of earthworms. 'It will get under way', he told me. It had been a potato plot for 10 years. The soil was anesthetized and there were no worms anymore. That was my first jolt in the field. I realized the magnitude of my ignorance about the life of the soil. (...) I learned my trade from that moment. It was the revelation of my career. (...) With him I had discovered everything that happens at the foot of a plant, the mycorrhizae, the importance of ground beetles, destruction of waste, etc. We had never heard about it before.'

The completion of attachment is also observable in the way in which the discourse of NutriAgri's representatives and farmers converge almost perfectly. The arguments of the former then become those of the latter, in what is reminiscent of other moral crusades observed in other markets (Biggart 1989). A technical sales representative told us that: 'Once we showed them we could get good results, [the farmers] criticized our competitors! There are even some that chuck them out when they criticize us. Or put a NutriAgri sticker above the barn.' Even though everyone is aware of maintaining an asymmetrical business relationship, where some sell to others, convinced producers and NutriAgri staff thus present their activity as teamwork, at farm level in the first instance, but then more broadly in the name of a certain vision of agriculture.

The fact that technical sales representatives will show themselves to be convinced by the solution they promote is also part of this movement. A technical sales representative from central France said he had cured his stomach problems by ingesting mineral supplement capsules produced by NutriAgri, originally intended for feeding calves. More generally, those technical sales representatives who are also farmers themselves tirelessly demonstrate their conversion and the benefits they have found on their own farms. One of them points out, once again indicating the almost religious journey that initiates the process from revelation to propagation: 'I would not have gone on the road to talk about it if I had not seen the results at home.' 
Technical events organized by the company also reflect the strength of the ties that have been established. They attract many farmers who are searching for an opportunity to get to know each other, to be convivial and to facilitate the exchange of experience, on the model of a community of practice. But at the same time, they are also a moment of reaffirmation of binding values. Epistemic community and moral community are also not separated, as evidenced by the terms of the discourse of a grain farmer who had been a customer for six years: 'The good point is also the group. We all feel a little bit as if we are pioneers with an investigative role, the search for solutions.'

\section{Conclusion}

How does one sell an uncertain product? This question, which relates to a classic research problem, is also the practical issue faced by NutriAgri staff. In this case, our survey shows that the uncertain nature of the technology is not the result of an information asymmetry between actors of supply and demand over the characteristics of the product. Even if such an asymmetry exists in terms of the active constituents of the 'core', the technical sales representatives of NutriAgri never correct it. Uncertainty is mainly focused on the beneficial or harmful effects of the product, which are the object of a continuous qualification battle whose practical form can be described as activities of detachment and attachment. Thus, given this uncertainty constantly put forward by opponents, NutriAgri must detach farmers from a wide range of entities, from phosphorus to the institutions of agricultural science. It is this work that makes it possible to start up new assessments and new attachments. The latter are generated through a focus on the product, but not only that, to the point where some farmers mentioned this commitment as a true conversion. Attachment is not carried out with the product alone. The latter is 'dissolved' in a global solution made up from advice and support, auxiliary soil fauna and the tools to observe them, of farmers and sellers as team-mates, of self-image and a 'new vision of agriculture'. Finally, confidence is not the result of a perfect clarification of the characteristics and benefits of the product, but the result of the range of successful associations. One farmer said: 'I don't really believe in it. I was more convinced by what was said than by the snake oil ['poudre de perlimpinpin' in French]. But the testimony of other users on their practices, its consistency with what was said, the overall vision, made me let go and gain confidence.' These attachments may nevertheless remain fragile. They are in any case contested by the re-attachment attempts of competitors who reaffirm the inefficiency and dangers of the use of NutriAgri's products. Even when customers are convinced of the 
quality of its products, NutriAgri's representatives still have to maintain the detachments and attachments that are favourable to them.

By focusing on the work of detachment and attachment carried out by NutriAgri's sales staff, we were able to understand to what extent the dynamics of competition in the market is not just concerned with products. Although the market we have studied is one in which only products are bought and sold, these transactions cannot be understood without also taking account of the consulting service that the sellers provide. In the case studied here, this does not simply mean that free advice is available in the same sense as, for example, free home delivery is provided in addition to the purchase of a good. In the dynamics of competition we have observed, the advisory service does not only add value to the goods being supplied; it is also the basis of a fundamental reappraisal of the practices and representations of buyers, and therefore the modes of evaluation of the goods being offered for sale.

This research is therefore in line with many studies that have confirmed the relevance of the framework of Callon et al. (2002) for the analysis of market activities. But it helps to deepen the analysis of mechanisms of detachment that have hardly been explored compared to the processes of attachment. Indeed the empirical case study makes it possible to see the centrality of detachment activities in the construction of the market. Beyond that contribution to and deepening of ANT, we believe that this analysis of the process of detachment is a path to be considered for following contemporary developments affecting the defining qualities of products. As more and more frequently in areas such as food, agriculture or cosmetics, the qualities of products are defined less by what they contain than in terms of what they do not contain (pesticides, GMO, palm oil, trans fats, added sugar, parabens, etc., see Goulet and Vinck 2012). The detachment of the consumer - and beyond that, the producer - vis-à-vis these prohibited or non-desirable elements slowly but surely becomes a key element of the definition of quality at the heart of commercial activity. It is thus not only the mechanisms of detachment, but also their importance respective to the attachment process, which we think should be considered in continuing the analysis of market processes.

\section{References}

Akerlof, George A. 1970. "The market for "lemons": Quality uncertainty and the market mechanism." The Quarterly Journal of Economics 84 (3):488-500. 
Aspers, Patrik, and Asaf Darr. 2011. "Trade shows and the creation of market and industry." The Sociological Review 59 (4):758-778.

Azimont, Frank, and Luis Araujo. 2007. "Category reviews as market-shaping events." Industrial Marketing Management 36 (7):849-860.

Barrey, Sandrine. 2007. "Struggling to be displayed at the point of purchase: the emergence of merchandising in French supermarkets." In Market devices, edited by F. Muniesa, Y. Millo and M. Callon. Oxford: Blackwell.

Beckert, Jens. 1996. "What is sociological about economic sociology? Uncertainty and the embeddedness of economic action." Theory and Society 25 (6):803-840.

Biggart, Nicole Woolsey. 1989. Charismatic capitalism: Direct selling organizations in America. Chicago: University of Chicago Press.

Bird-David, Nurit, and Asaf Darr. 2009. "Commodity, gift and mass-gift: on gift-commodity hybrids in advanced mass consumption cultures." Economy and Society 38 (2):304-325.

Buller, Henry, and Emma Roe. 2013. "Modifying and commodifying farm animal welfare: The economisation of layer chickens." Journal of Rural Studies (forthcoming).

Çalışkan, Koray, and Michel Callon. 2010. "Economization, part 2: a research programme for the study of markets." Economy and Society 39 (1):1-32.

Callon, Michel. 1981. "Pour une sociologie des controverses technologiques." Fundamenta Scientiae 2 (3/4):381-399.

Callon, Michel. 1986. "Some elements of a sociology of translation. Domestication of the Scallops and the Fishermen of St. Brieuc Bay." In Power, Action and Belief. A new Sociology of Knowledge?, edited by J. Law. London: Routledge.

Callon, Michel, Cécile Méadel, and Vololona Rabeharisoa. 2002. "The economy of qualities." Economy and Society 31 (2):194-217.

Callon, Michel, and Fabian Muniesa. 2005. "Economic Markets as Calculative Collective Devices." Organization Studies 26 (8):1229-1250.

Cochoy, Franck. 2004. "Is the modern consumer a Buridan's donkey? Product packaging and consumer choice." In Elusive consumption, edited by K. M. Ekström and H. Brembeck. Oxford: Berg. 
Cochoy, Franck. 2007. "A Brief Theory of the 'Captation' of Publics: Understanding the market with Little Red Riding Hood." Theory, Culture \& Society 24 (7-8):203-223.

Cochoy, Franck. 2008. "Calculation, qualculation, calqulation: shopping cart arithmetic, equipped cognition and the clustered consumer." Marketing theory 8 (1):15-44.

Cochoy, Franck, and Sophie Dubuisson-Quellier. 2013. "The Sociology of Market Work." Economic sociology the european electronic newsletter 15 (1):4-11.

Deville, Joe. 2012. "Regenerating market attachments. Consumer credit debt collection and the capture of affect." Journal of Cultural Economy 5 (4):423-439.

Doganova, Liliana, and Marie Eyquem-Renault. 2009. "What do business models do?: Innovation devices in technology entrepreneurship." Research policy 38 (10):15591570 .

Dubuisson-Quellier, Sophie. 2010. "Product tastes, consumer tastes: The plurality of qualification in product development and marketing activities." In Reconnecting marketing to markets, edited by L. Araujo, J. Finch and H. Kjellberg. Oxford: Oxford University Press.

Dubuisson-Quellier, Sophie. 2013. "A Market Mediation Strategy: How Social Movements Seek to Change Firms' Practices by Promoting New Principles of Product Valuation." Organization Studies 34 (5-6):683-703.

Goulet, Frédéric. 2013. "Narratives of experience and production of knowledge within farmers' groups." Journal of rural studies 32 (0):439-447.

Goulet, Frédéric, and Dominique Vinck. 2012. "Innovation through Withdrawal. Contribution to a Sociology of Detachment." Revue Française de Sociologie (English) 53 (2):117146.

Hennion, Antoine. 2004. "Pragmatics of taste." In The Blackwell Companion to the Sociology of Culture, edited by M. Jacobs and N. Hanrahan. Oxford: Blackwell,.

Karpik, Lucien. 2010. Valuing the unique: The economics of singularities. Princeton: Princeton University Press.

Kjellberg, Hans. 2007. "The death of a salesman? Reconfiguring economic exchange in Swedish post-war food distribution." In Market devices, edited by F. Muniesa, Y. Millo and M. Callon. Oxford: Blackwell. 
Latour, Bruno. 1988. The pasteurization of France. Cambridge Mass: Harvard University Press.

Latour, Bruno. 2005. Reassembling the social : an introduction to actor-network-theory. Oxford: Oxford University Press.

MacKenzie, Donald, and Yuval Millo. 2003. "Constructing a market, performing theory: the historical sociology of a financial derivatives exchange." American journal of sociology 109 (1):107-145.

Mallard, Alexandre. 2012. "Developing uses, qualifying goods: on the construction of market exchange for Internet access services." Consumption Markets \& Culture 15 (2):191211.

McFall, Liz. 2009a. "The agencement of industrial branch life assurance." Journal of Cultural Economy 2 (1-2):49-65.

McFall, Liz. 2009b. "Devices and Desires: How Useful Is the 'New' New Economic Sociology for Understanding Market Attachment?" Sociology Compass 3 (2):267-282.

Musselin, Christine, and Catherine Paradeise. 2005. "Quality: a debate." Sociologie du Travail 47 (S1):89-123.

Poon, Martha. 2009. "From new deal institutions to capital markets: Commercial consumer risk scores and the making of subprime mortgage finance." Accounting, Organizations and Society 34 (5):654-674.

Reijonen, Satu, and Kjell Tryggestad. 2012. "The dynamic signification of product qualities: on the possibility of "greening" markets." Consumption Markets \& Culture 15 (2):213234.

Trompette, Pascale. 2007. "Customer Channeling Arrangements in Market Organization: Competition Dynamics in the Funeral Business in France." Revue française de sociologie (English) 48 (5):3-33.

Van Hoyweghen, Ine. 2013. "On the Politics of Calculative Devices. Performing life insurance markets." Journal of Cultural Economy 7 (3):334-352.

Vatin, François. 2013. "Valuation as Evaluating and Valorizing." Valuation Studies 1 (1):3150. 
Waller, David S., Fam, Kim-Shyan, Erdogan, Bayram Zafer. 2005. "Advertising of controversial products: a cross-cultural study." Journal of Consumer Marketing 22 (1):6-13. 